Int. Archs Allergy appl. Immun. 1981;66(Suppl. 1):I-VI

\title{
Contents, Vol. 66, Supplement 1, 1981
}

Cellular Interactions in Allergy

13th Symposium of the Collegium Internationale AUergologicum, Konstanz, July 27-31,1980

Editors

Flemming Kristensen, Bern Alain L. de Week, Bern Peter Dukor, Basel

112 figures and 66 tables, 1981

S. Karger · Basel · München · Paris · London · New York · Sydney

Transactions of the Collegium Internationale AUergologicum

1 st-9th Symposium, please ask for details 10th Symposium in Copenhagen, 1974.

Molecular and Cellular Aspects of Allergy.

Edited by B. Diamant (Copenhagen), P.

Kallós (Helsingborg), H. Rorsman (Lund)

and G.B. West (Epsom, Surrey).

IV + 284 p., 98 fig., 50 tab., 1975.

(Separatum vol. 49, No. 1-2 International

Archives of Allergy and Applied

Immunology.)

ISBN 3-8055-2166-9 11th Symposium in Heidelberg, 1976. Mediators

of the Immediate Type Inflammatory

Reaction. Edited by Klaus O. Rother (Heidelberg) and A.L. de Week (Bern). VIII + 256 p., 100 fig., 37 tab., 1977. (Monographs in Allergy, Vol. 12.) ISBN 3-8055-2660-1 12th Symposium in New Orleans, 1978. New Approaches to the Management of Allergic Diseases. Edited by L.M. Lichtenstein (Baltimore, Md.) and G.J. Gleich (Rochester, Minn.). VIII + 330 p., 112 fig., 56 tab., 1979. (Monographs in Allergy, Vol. 14.) ISBN 3-8055-3039-0

\section{Drug Dosage}

The author and publisher have exerted every effort to ensure that drug selection and dosage set forth in this text are in accord with current recommendations and practice at the time of publication. However, in view of ongoing research, changes in government regulations, and the constant flow of information relating to drug therapy and drug reactions, the reader is urged to check the package insert for each drug for any change in indications and dosage and for added warnings and precautions. This is particularly important when the recommended agent is a new and/or infrequently employed drug.

All rights reserved.

No part of this publication may be translated into other languages, reproduced or utilized in any form or by any means, electronic or mechanical, including photocopying, recording, microcopying, or by any information storage and retrieval system, without permission in writing from the publisher.

S. Karger AG, P.O. Box, CH-4009 Basel (Switzerland) 
Printed in Switzerland by Buchdruckerei National-Zeitung + Basler Nachrichten AG, Basel

ISBN 3-8055-3439-6

Contents

Regulation of the IgE Response

Regulation of the IgE Antibody Response. Introduction

Ishizaka, K 1

IgE Production and Suppression in Mice. Carl Prausnitz Memorial Lecture

Ovary, Z 8

Genetic Control of the IgE Reaginic Immune Response

Bazin, H.; Platteau, B.; Pauwels, R 19

New Concepts Concerning Pathogenesis of the Allergic Phenotype and Prospects for Control of IgE

Antibody Synthesis

Katz, D.H 25

Tl 5-Idiotype Positive, IgE Class-Specific Suppressor T Cells and Characterization of the Suppressor

Factor

Kishimoto, T.; Sugimura, K; Suemura, M.; Shiho, O.; Maeda, K.; Yamamura, Y.; Böttcher, 1 31

Specific Downregulation of IgE Antibodies by Tolerogenic Conjugates of Haptens and Allergens with

Synthetic Polymers

Sehon, A.H.; Lee, W.Y

39

Newer Developments in Immunotherapy for Hay Fever

Norman, P.S 43

Elicitation and Regulation Mechanisms in the Immediate Type Allergic Response

Association of HLA Phenotypes Al, B8, DW3 and A3, B7, DW2 with Allergy

Marsh, D.G.; Meyers, D.A.; Freidhoff, L.R.; Hussain, R.; Hsu, S.H.; Bias, W.B 48

Genetic Polymorphism (Igh-7 Allotype) Detected on Murine IgE

Borges, M.S.; Kumagai, Y.; Okumura, K.; Tada, T 51

Synthesis of Human IgE in vitro in Normals and High IgE Atopy

Saxon, A.; Stevens, R.H 55

Secondary Challenge Results in Anti-Phosphocholine Response in Immunodefective Male

(Balb/c $\times$

$\mathrm{CBA} / \mathrm{N}) \mathrm{F}[$ Mice

Levy, D.A.; Cebra, J.J.; Clough, E 58

Regulation of the IgE Antibody Response by Anti-Idiotypic Antibodies and Its Resolution into Hapten- and Carrier-Specific Compartments

Blaser, K.; Nakagawa, T.; Week, A.L. de 61

Specific Desensitization in Inbred Guinea Pigs

Ibsen, P.; Lundberg, L.; Lind, P.; Løwenstein, H.; Weeke, B

In vitro Production of Anti-mite IgE Antibody and its Suppression by Human Peripheral Blood

Lymphocytes

Iwamoto, I.; Nawata, Y.; Yanagisawa, T.; Yoshida, S.; Itaya, T.; Tomioka, H.; Kumagai, A

67

Pathomechanism of Dextran-Induced Anaphylactoid Reactions in Man 
Hedin, H.; Richter, W.; Kraft, D 75

Loss of IgE Receptors and Shedding of a Protease during Purification of Mast Cells

Coutts, S.M.; Nehring, R.; Jariwala, N.; Weinryb, I.; Khandwala, A 78

Direct Evidence for the Heterogeneity of the IgE and the IgGi Receptor on Murine Mast Cells

Böttcher, I.; Albring, M 82

Immunological Evidence for IgE Complexes following Food Challenge in Atopies

Brostoff, J.; Carini, C; Wraith, D.G 87

IV

Contents

Effect of Inhaled Hapten-Protein Conjugates on the Respiratory Epithelium, Assessed Using the

Scanning Electron Microscope

Beeson, M.F.; Dewdney, J.M 89

Atopy and Adverse Drug Reactions

Ettlin, R.; Hoigné, R.; Bruppacher, R.; Müller, U.; Stocker, F 93

Castor Bean Allergy in the Sudan

Kemeny, D.M.; Frankland, A.W.; Fakhri, Z.I.; Trull, A.K 96

Mediators of Allergic Reactions and Factors Affecting Their Releasability

Leukotrienes: Mediators of Allergic Reactions and Inflammation

Samuelsson, B 98

SRS-A and SRS: Their Structure, Biosynthesis and Actions

Piper, P.J.; Samhoun, M.N.; Tippins, J.R.; Morris, H.R.; Jones, CM.; Taylor, G.W 107

Possible Role of Serum Anaphylatoxins in Hypersensitivity Reactions

Hugh, T.E.; Stimler, N.P.; Gerard, C; Moon, K.E 113

Platelet-Activating Factor (PAF-acether): Molecular Aspects of Its Release and Pharmacological

Actions

Benveniste, J.; Jouvin, E.; Pirotzky, E.; Arnoux, B.; Mencia-Huerta, J.M.; Roubin, R.; Vargaftig, B.B. 121 Acetyl Glyceryl Ether Phosphorylcholine: Platelet-Activating Factor

Pinckard, R.N.; McManus, L.M.; Halonen, M.; Hanahan, DJ

127

Quantitative Electron Microscopy of Sensitized Rat Mast Cells

Hertel, G.; Bindewald, J.; Brassel, D.; Behrendt, H 137

Variation in Mast Cell Numbers in Sensitized Rats Associated with Altered Immediate

Pulmonary

Hypersensitivity

Carswell, F.; Oliver, J 140

Flow Cytometric Analysis of Human Basophil Degranulation Induced by Antibodies and Allergens

Nakagawa, T.; Heiner, D.C.; Skvaril, F.; Week, A.L. de

Control Mechanisms of Histamine Release from Human Basophils in vitro: The Role of

Phospholipase A2 and of Lipoxygenase Metabolites

Marone, G; Kagey-Sobotka, A.; Lichtenstein, L.M 144

Effect of Arachidonic Acid Metabolites on the Histamine Release from Human Basophils and

Rat

Mast Cells

König, W.; Pfeiffer, F.; Kunau, H.W 149

Effect of Aspirin and Indomethacin on Histamine Release from Leukocytes of Patients with

Suspected 
Intolerance to Aspirin

Conroy, M.C.; Week, A.L. de 152

Acetylsalicylic Acid Intolerance: A Possible Role of Complement

Voigtländer, V.; Hänsch, G; Rother, U 154

Increased Vasoactive Mediator Releasability: A Possible Pathogenic Factor of Atopic Dermatitis Ring, J 156

Antigen-Induced Release of Esterase (Protease) Activity from Rat Mast Cells as a Modulator of Type I

Allergic Reaction?

Wilhelms, O.-H.; Roesch, E 159

Activation of the Hageman Factor-Dependent Systems during IgE-Mediated Reactions of the Human

Lung

Newball, H.H.; Meier, H.L.; Kaplan, A.P.; Revak, S.D.; Cochrane, C.G; Lichtenstein, L.M

165

Comparison of the Eosinophil Chemotactic Factor (ECF) with Endogeneous

Hydroxyeicosatetraenoic

Acids of Leukocytes

König, W.; Kroegel, C; Kunau, H.W.; Borgeat, P 168

Contents

$\mathrm{V}$

Further Characterization of the Neutrophil-Derived Eosinophil Chemotactic Factor and

Comparison

to Eosinophil Chemotactic Activity from Mast Cells

Czarnetzki, B.M.; Zimmermann, R.E.; Fischer, N 172

Impairment of the Platelet-Activating Factor Release from Elicited Peritoneal Macrophages

Roubin, R.; Mencia-Huerta, J.M.; Benveniste, J 174

Platelet-Activating Factor (PAF-acether) Is Released from Isolated Perfused Rat Kidney

Pirotzky, E.; Benveniste, J 176

Acetyl Coenzyme A (Ac-CoA) and Sodium Acetate Enhance the Release of Platelet-Activating Factor

(PAF-acether) from Murine Peritoneal Cells

Mencia-Huerta, J.M.; Roubin, R.; Benveniste, J 178

In vivo Activation of Macrophages by Corynebacterium parvum, Pyran Copolymer and Glucan.

Differential Effects on Prostaglandin E Release, Tumor Cytotoxicity and Lymphocyte

Stimulation

Bärlin, E.; Leser, H.-G.; Deimann, W.; Resch, K.; Gemsa, D

Macrophage Activation by Various Stimuli Is Mediated by Endogenous C3

Schorlemmer, H.U.; Seiler, F.R.; Bitter-Suermann, D 183

Regulation of Delayed Type Hypersensitivity

Major Histocompatibility Gene Complex and Delayed Hypersensitivity

Miller, J.F.A.P 188

The Role of T Cell Subsets and la Antigens in Delayed-Type Hypersensitivity

Basten, A 197

Antigen-Specific and Nonspecific Suppressor Factors Derived from T Cell Hybridomas:

Their Function and Molecular Organization 
Taniguchi, M.; Takei, I.; Saito, T.; Igarashi, M.; Kurihara, K.; Tomioka, H 204

Anti-Idiotypic Specificity of T Cell Help Induced by Concanavalin A

Primi, D.; Lewis, G.K.; Goodman, J.W 212

Cellular and Molecular Aspects of Lymphocyte Macrophage Interactions

Sorg, C; Neumann, C 218

Role of Histamine in the Regulation of Cell-Mediated Immunity

Askenase, P.W.; Schwartz, A.; Siegel, J.N.; Gershon, R.K 225

A Role for Cytoplasmic Vesicles in Anaphylactic Degranulation of Guinea Pig Basophils

Dvorak, A.M.; Galli, S.J.; Dvorak, H.F 234

Chemistry and Standardization of Allergens

Standardization of Allergen Extracts

Gleich, G.J.; Adolphson, C; Yunginger, J.W 239

Solid Phase Allergens and IgE Antibodies for the Determination of Allergen Extract Potency

Schroder, H.; Andrae, M.-L; Yman, L

Histamine Release from Isolated Guinea Pig Mast Cells as Bioassay System for the

Standardization of

Allergens

Fischer, B.; Schmutzler, W 250

Standardization of Allergens: Lectins and Monoclonal Antibodies as Primary Standards for House

Dust Mite Allergens

Krilis, S.; Baldo, B.A.; Basten, A 252

Cross-Reactions between Vegetable Foods, Pollen and Bee Venom Due to IgE Antibodies to a

Ubiquitous Carbohydrate Determinant

Aalberse, R.C.; Koshte, V.; Clemens, J.G.J 259

VI Contents

Direct Detection of Specific Serum IgE Antibodies to Electrophoretically Separated Honey Bee Venom Allergens

Schroder, H.; Andrae, M.-L 261

Relevance of Allergen Concentration and Distribution to the Immune Response to Inhalant

Allergens

in Man

Platts-Mills, T.A.E.; Chapman, M.D.; Tovey, E.R 264

Anti-Allergic Therapy

Criteria for the Clinical Evaluation of Anti-Allergic Therapy

Pepys, J 266

Criteria for the Clinical Evaluation of Prophylactic Agents in Bronchial Asthma

Craps, L 272

Antiallergic Activity of Tiaramide Hydrochloride (RHC 2592-A)

Khandwala, A.; Coutts, S.; Krusko, D.; Ryan, A.; Weinryb, I

Comparison of Sodium Cromoglycate Derivatives, Anti-Histamines and ß-Stimulants on

Histamine

Release from Human Lung in vitro

Church, M.K.; Young, K.D 281

Evaluation of Immediate- and Late-Response Inhibition of a New Beta-Agonist, KWD 2131,

Compared with Terbutaline and DSCG 
Hegardt, B.; Pauwels, R.; Van der Straeten, M

In vivo Antianaphylactic Effect of Terbutaline

Radermecker, M.; Gustin, M 286

Hapten Inhibition in the Dextran Antidextran System and Its Application to Prevent Dextran Anaphylaxis in Man

Richter, W.; Hedin, H.; Messmer, K.; Ljungström, K.-G 288

The Possibility of Affecting Allergic Reactions by Histamine-Gamma-Globulin Compound

Fuchs, E.; Gronemeyer, W.; Brückner-de Velliet, M 291

Development and Evaluation of Polymerized Allergens for Immunotherapy

Patterson, R.; Suszko, I.M.; Zeiss, C.R.; Pruzansky, J.J 293 